\title{
Komponen Flavor Volatil Tempe yang Dibungkus dengan Daun Pisang dan Plastik
}

\author{
Volatile Flavor Compounds of Tempeh Wrapped With Banana Leaf and Plastic \\ Rasyid Hanafi Harahap ${ }^{1 *}$, Zulkifli Lubis ${ }^{1}$, Jamaran Kaban² \\ ${ }^{1}$ Program Studi IImu Pangan, Fakultas Pertanian, Universitas Sumatera Utara, JI. Prof. Dr. A. Sofyan No. 3, Kampus \\ USU Medan Sumatera Utara 20155, Indonesia \\ 2Program Studi Kimia, Fakultas Matematika dan Ilmu Pengetahuan Alam (FMIPA), Universitas Sumatera Utara, Jl. \\ Bioteknologi No. 1 Kampus USU Medan Sumatera Utara 20155, Indonesia \\ Email: rasyidhh213@gmail.com
}

Tanggal submisi: 2 Mei 2017; Tanggal penerimaan: 13 Februari 2018

\begin{abstract}
ABSTRAK
Penelitian ini bertujuan untuk mengetahui komponen penyusun flavor volatil dan aroma tempe yang dibungkus daun pisang dan plastik pada waktu fermentasi yang berbeda-beda. Tempe yang digunakan sebagai objek penelitian adalah tempe yang dibungkus dengan daun pisang (TD) dengan waktu fermentasi 48 jam (TD1H), 72 jam (TD2H), dan 96 jam (TD3H) dan tempe yang dibungkus plastik (TP) dengan waktu fermentasi 48 jam (TP1H), 72 jam (TP2H), dan 96 jam (TP3H). Ekstraksi sampel tempe menggunakan HS-SPME. Analisis flavor dan deskripsi odor dilakukan dengan menggunakan GC-MS/O. Senyawa flavor tempe yang diperoleh adalah senyawa-senyawa dari golongan ester, terpenoid, alkohol, aldehid, keton, furan dan senyawa-senyawa yang mengandung nitrogen. a-pinen hanya ditemukan pada tempe yang dibungkus daun pisang, sedangkan piperazin, sec-butil nitrit dan (Z)-a-bisabolen hanya ditemukan pada tempe yang dibungkus plastik saja. Hal ini berarti ada perbedaan komponen penyusun senyawa flavor pada tempe yang dibungkus daun pisang dan plastik.
\end{abstract}

Kata kunci: Flavor; GC-MS/O; SPME; tempe

\section{ABSTRACT}

The objective of the research was to identify volatile flavor compounds and odor description of tempeh wrapped with banana leaf and plastic fermented at different times. The research object was tempeh wrapped with banana leaf (TD) at $48(\mathrm{TD} 1 \mathrm{H}), 72(\mathrm{TD} 2 \mathrm{H})$, and 96 hours (TD3H) fermented, and tempeh wrapped with plastic (TP) at 48 (TP1H), 72 (TP2H), and 96 hours (TP3H) fermented. Sample was extracted by SPME. GC-MS/O was used to identify volatile flavor compounds and odor description. The volatile flavor compound found in tempeh were group of ester, terpenoid, alcohol, aldehyde, ketone, furan and nitrogen containing compound. a-pinene was only found in tempeh wrapped with banana leaf, whereas piperazine, sec-butyl nitrite and (Z)-a-bisabolene were only found in tempeh wrapped with plastic. This revealed that there was difference flavor compound found in tempeh wrapped with banana leaf and tempeh wrapped with plastic.

Keywords: Flavor; GC-MS/O; SPME; tempeh

\section{PENDAHULUAN}

Tempe adalah salah satu makanan tradisional khas Indonesia yang dibuat dari biji kedelai yang diproses melalui proses fermentasi dengan bantuan starter atau lebih dikenal dengan sebutan "ragi tempe". Seiring perkembangannya, saat ini tempe telah dikenal sebagai makanan sehat yang mengandung nutrisi-nutrisi penting untuk kesehatan manusia.

Fermentasi adalah salah satu tahapan terpenting dalam memproduksi tempe yang akan menghasilkan senyawa-senyawa sederhana yang mudah dicerna. Proses ini juga juga yang menghasilkan senyawasenyawa yang menyebabkan tempe memiliki rasa dan aroma khas.

Tempe yang banyak dijumpai, khususnya di pasarpasar tradisional, adalah tempe yang dikemas dengan daun pisang dan plastik. Daun pisang merupakan bahan pembungkus yang banyak digunakan untuk membungkus makanan-makanan tradisional Indonesia. Bahan ini digunakan karena murah dan mudah didapat. Sebelum produk tempe dikenal secara luas, pembuatan tempe selalu menggunakan daun sebagai bahan 
pembungkus seperti daun pisang dan daun jati. Hingga pada akhir tahun 1960-an atau awal taun 1970-an pengrajin tempe mulai menggunakan bahan plastik (polietilen) sebagai pembungkus menggantikan daun pisang (Shurtleff \& Aoyagi, 1979).

Perkembangan teknologi pembuatan tempe yang semakin luas membuat teknologi tradisional tempe di Indonesia semakin tersingkir. Salah satunya adalah perkembangan penggunaan plastik polietilen sebagai pembungkus. Namun, masyarakat Indonesia masih meyakini bahwa tempe yang dibungkus dengan daun pisang memiliki kualitas yang lebih baik, terutama aroma yang dihasilkan.

Penelitian mengenai komponen pembentuk aroma pada tempe perlu dilakukan seperti yang disarankan oleh Kustyawati, (2009) karena data mengenai senyawa volatil khususnya yang berperan pada aroma tempe masih sangat terbatas (Mei Feng, Ostenfeld Larsen, \& Schnürer, 2007). Penelitian ini bertujuan untuk mengetahui apakah terdapat perbedaan profil senyawa flavor volatil pada tempe yang dibungkus daun pisang dengan tempe yang dibungkus plastik dengan waktu fermentasi yang berbeda-beda.

\section{METODE PENELITIAN}

Sampel tempe dibuat menggunakan kedelai kuning impor, ragi komersial (merk RAPRIMA, produksi PT. Aneka Fermentasi Industri, Bandung). Pembuatan tempe diawali dengan penyortiran biji kedelai, setelah itu dilakukan perendaman selama 1 malam. Selanjutnya dilakukan penggilingan untuk membuang kulit biji kedelai. Tahap berikutnya adalah perebusan, penirisan dan inokulasi. Perbandingan inokulum dan kedelai yang digunakan adalah $2 \mathrm{~g} / \mathrm{kg}$ (berat kering). Tahap berikutnya adalah pembungkusan menggunakan daun pisang dan plastik polietilen. Fermentasi dilakukan selama 48 jam, 72 jam, dan 96 jam.

Sampel tempe yang digunakan adalah sampel tempe yang dibungkus daun pisang dengan waktu fermentasi 48 jam (TD1H), 72 jam (TD2H), 96 jam (TD3H) dan tempe yang dibungkus plastik dengan waktu fermentasi 48 jam (TP1H), 72 jam (TP2H), dan 96 jam (TP3H). Masingmasing sampel tempe dihaluskan (shredded) dan $5 \mathrm{~g}$ sampel kemudian dimasukkan ke dalam botol vial $20 \mathrm{~mL}$, ditutup rapat dengan septum silikon dan siap untuk dilakukan proses ekstraksi.

Ekstraksi senyawa volatil sampel dilakukan menggunakan alat ekstraksi SPME (Supelco, USA). Prakondisi SPME dilakukan sebelum digunakan untuk ekstraksi dengan cara menempatkan holder SPME pada injection port GC (Agilent Technologies 7890A, USA) seperti ketika akan mendesorpsi sampel. Suhu injection port diatur pada $250{ }^{\circ} \mathrm{C}$. Prakondisi ini bertujuan untuk membersihkan fiber SPME dari senyawa-senyawa yang mungkin saja melekat pada fiber. Optimasi ekstraksi dilakukan dengan mengamati beberapa parameter agar mendapatkan kondisi yang seimbang (equilibrium) antara sampel dengan fiber SPME. Parameter-parameter dimaksud adalah jenis fiber yang berbeda DVB/PDMS dan CAR/PDMS, waktu ekstraksi selama 15, 30, dan 45 menit, serta suhu ekstraksi $40^{\circ} \mathrm{C}$.

Kondisi equilibrium diketahui dari kromatogram yang dihasilkan setelah ekstrak sampel diinjeksikan ke GC. Jenis fiber serta kombinasi suhu dan waktu ekstraksi yang menghasilkan pemisahan puncak kromatogram yang lebih baik, maka akan digunakan untuk pemeriksaan sampel. Kondisi GC-MS/O (MS Agilent Technologies 5975C, USA; Olfactometer Gerstel, USA) yang digunakan untuk memperoleh hasil yang optimal adalah sebagai berikut: Suhu injector $250^{\circ} \mathrm{C}$ split less, gas pembawa helium dengan kecepatan aliran 0,8 $\mathrm{mL} /$ menit. Column DB-WAX $30 \mathrm{~m} \times 250 \mu \mathrm{m} \times 0,25 \mu \mathrm{m}$ (Agilent, USA). Suhu awal oven $40{ }^{\circ} \mathrm{C}$ dan langsung dinaikkan $5^{\circ} \mathrm{C} /$ menit hingga mencapai suhu $200{ }^{\circ} \mathrm{C}$ dan ditahan selama 5 menit. Sumber energi ionisasi MS adalah electron ionization (EI) 70 eV dengan scan massa 33-550 amu dan suhu sumber ion $230^{\circ} \mathrm{C}$. MS dilengkapi dengan software library NIST08.L (Release 2008, USA). Kondisi GC-MS yang menghasilkan kromatogram dengan pemisahan yang terbaik akan digunakan untuk pemeriksaan sampel. Serangkaian seri alkana juga diinjeksikan untuk digunakan menghitung indeks retensi masing-masing senyawa.

\section{HASIL DAN PEMBAHASAN}

\section{Jenis Fiber}

Dua jenis fiber DVB/PDMS (Sigma-Aldrich, Germany) dan CAR/PDMS (Sigma-Aldrich, Germany) digunakan untuk memperoleh fiber yang memiliki sensitifitas lebih baik pada sampel tempe segar.

Hasilnya diperoleh kromatogram dengan 9 puncak dengan menggunakan fiber DVB/PDMS dan 19 puncak dengan menggunakan fiber CAR/PDMS. Hal ini berarti untuk sampel tempe yang digunakan, fiber CAR/PDMS lebih sensitif diabanding fiber DVB/PDMS.

\section{Waktu dan Suhu Ekstraksi}

SPME membutuhkan waktu untuk mencapai kondisi keseimbangan (equilibrium). Waktu ekstraksi yang digunakan untuk memperoleh waktu yang tepat adalah 15, 30, dan 45 menit pada suhu $40^{\circ} \mathrm{C}$.

Puncak yang dihasilkan pada kromatogram dengan lama ekstraksi 15 menit adalah sebanyak 9 puncak. Sedangkan pada kromatogram yang dihasilkan dengan lama ekstraksi 30 dan 45 menit masing-masing adalah 15 dan 19 puncak. Dari data ini maka lama ekstraksi 45 menit merupakan waktu yang lebih tepat untuk sampel tempe segar.

\section{Optimasi Kolom}

Kolom sangat menentukan dalam pemisahan senyawa oleh GC. Untuk memperoleh kolom yang tepat dan lebih sensitif terhadap sampel tempe segar, digunakan dua jenis kolom yaitu DB-WAX dan HP-5MS $30 \mathrm{~m} \times 250 \mu \mathrm{m} \times 0.25 \mu \mathrm{m}$ (Agilent, USA). 
Puncak kromatogram yang dihasilkan dengan menggunakan kolom DB-WAX sebanyak 39 sedangkan puncak kromatogram yang dihasilkan dengan menggunakan kolom HP-5MS sebanyak 31. Hal ini berarti kolom DB-WAX lebih sensitif dibanding dengan kolom HP5MS, sehingga akan digunakan sebagai kolom dalam analisis sampel.

\section{Hasil Analisis Flavor}

Hasil analisis senyawa flavor tempe disajikan pada Tabel 1. Komponen flavor tempe terdiri dari senyawa golongan ester, terpenoid, alkohol, aldehid, keton, furan, dan senyawa-snyawa mengandung nitrogen.

\section{Golongan Ester}

Ada tiga senyawa dari golongan ester yang ditemukan pada sampel tempe yaitu metil 3-metilbutanoat, etil 3metilbutanoat dan etil fenilasetat. Berdasarkan luas areanya, metil 3-metilbutanoat dan etil 3-metilbutanoat berperan penting dalam memberikan aroma tempe pada TD1H dan TP1H, sedangkan ethyl fenilasetat tidak memiliki area yang luas.

Luas area metil 3-metilbutanoat pada TD1H adalah $2,51 \%$, pada TP1H luas areanya lebih besar yaitu $6,34 \%$. Etil 3-metilbutanoat pada TD1H memiliki luas area 3,72\% dan $2,34 \%$ pada TP1H. Pada produk hasil fermentasi, ester diproduksi oleh kapang melalui reaksi esterifikasi antara asam organik hasil metabolisme asam lemak dengan alkohol (Liu, Miao, Guan, \& Sun, 2012) dan pematangan (aging) (Fan \& Qian, 2005). Reaksi ini dikatalisis oleh enzim alkohol karboksilesterase dan arylesterase (Carballo, 2012).

Pada penelitian sebelumnya dilaporkan bahwa senyawa golongan ester tidak berperan dalam pembentukan flavor tempe (Jeleń, Majcher, Ginja, \& Kuligowski, 2013), sedangkan Apriyantono, Nurkori, Nurjanah, \& Satiawihardja (2001) menemukan adanya senyawa golongan ester dalam pembentukan flavor tempe namun tidak menemukan metil 3-metilbutanoat, etil 3-metilbutanoat maupun etil fenilasetat. Perbedaan ini mungkin saja terjadi karena perbedaan starter yang digunakan (Supriyanto, Wada, Hayakawa, \& Fujio, 1991).

\section{Golongan Terpenoid}

Senyawa golongan terpenoid mendominasi flavor pada sampel tempe yang diuji. Sebelas jenis senyawa dari golongan ini ditemukan, antara lain adalah a-pinen, 1,8sineol, 9-metiltetrasiklo[7.3.1.0(2.7).1 (7.11)]tetradecan, a-kubeben, a-gurjunen, sitronellal, a-longipinen, karyopilen, a-terpineol, (Z)-a-bisabolen dan azulen.

Diantara senyawa-senyawa ditemukan tersebut akubeben, a-gurjunen, a-longipinen dan karyopilen merupakan senyawa-senyawa yang memiliki area yang paling luas. Sedangkan a-pinen menjadi pembeda antara TD dan TP karena hanya dijumpai pada sampel TD1H. Karyopilen yang pada tempe sebelumnya juga dilaporkan oleh Apriyantono et al., (2001).

Terpenoid merupakan komponen utama dari minyak atsiri yang didefinisikan sebagai senyawa metabolit sekunder yang terbentuk dari unit-unit isopren (2-metil1,3 buten). $\mathrm{Di}$ alam, terpenoid dibentuk dari penggabungan isopentenil difosfat (IPP) dan dimetilallil difosfat (DMAPP) yang diturunkan dari metabolisme asam asetat melalui jalur asam mevalonat.

\section{Golongan Alkohol}

Golongan alkohol yang ditemukan dari hasil analisis yaitu 2-metilpropanol, 3-metilbutanol, 1-heksanol, 1octen-3-ol, 2-metoxi-4-metilfenol dan 2-feniletanol. Senyawa yang sama juga dilaporkan oleh Apriyantono et al., (2001). 3-metilbutanol juga ditemukan Jeleń et al., (2013) pada tempe umur 5 hari dengan nilai OAV (odor activity value) < 1 (sangat kecil). Konsentrasi suatu senyawa berbanding lurus dengan nilai OAV-nya, karena nilai OAV diperoleh dari pembagian antara konsentrasi senyawa dengan konsentrasi threshold-nya. Hal ini berarti bahwa nilai OAV dapat dihitung jika konsentrasi senyawa diketahui. Sedangkan dalam penelitian ini konsentrasi senyawa diketahui secara kualitatif berdasarkan luas areanya, sehingga perlu penelitian lebih lanjut untuk dapat menentukan nilai OAV.

\section{Golongan Aldehid dan Keton}

Golongan aldehid yang ditemukan adalah (E)-tridec2-enal dan fenilasetaldehid, sedangkan golongan keton yang ditemukan adalah octan-3-on dan 2,3-dihidro-7metoxi-4-metil-1H-1,5-benzodiazepin-2-on. Sesuai dengan jalur proteolisis dan glikolisis, diketahui bahwa aldehid dihasilkan melalui jalur proteolisis dan lipolysis, sedangkan keton dihasilkan melalui jalur lipolysis. Beberapa senyawa keton seperti aseton, 2-butanon, dan 2,3-butanon dihasilkan dari piruvat yang dihasilkan dari jalur glikolisis (Carballo, 2012).

\section{Golongan Furan}

Senyawa dari golongan furan yang ditemukan pada penelitian ini adalah 2-pentilfuran. Senyawa ini juga ditemukan oleh Apriyantono et al., (2001). Senyawa golongan furan ini dikategorikan sebagai karsinogen, sehingga menjadi perhatian para peneliti bahkan pemerintah untuk melakukan identifikasi lebih mendalam (Vranová \& Ciesarová, 2009).

Furan dibentuk dari hasil oksidasi asam lemak selama proses pemanasan (Elmore, Campo, Enser, \& Mottram, 2002), reaksi maillard, degradasi asam amino, oksidasi asam askorbat (Yaylayan, 2006) ataupun merupakan hasil iradiasi (Vranová \& Ciesarová, 2009). Van Ba, Ryu, \& Inho (2012) melaporkan bahwa 2-pentilfuran berasal dari asam lemak $\mathrm{C} 18: 3 \mathrm{n} 3$.

Sangat sedikit catatan mengenai terbentuknya furan pada produk-produk fermentasi. Dalam laporan Apriyantono et al., (2001) diketahui bahwa furan terdeteksi pada tempe yang difermentasi selama 48 jam. Dalam penelitian ini furan dalam bentuk 2-pentilfuran ditemukan pada seluruh sampel. Berdasarkan luas areanya, 2-pentilfuran lebih dominan pada tempe yang 
dibungkus daun, utamanya pada tempe dengan waktu fermentasi 72 jam.

\section{Golongan Senyawa Mengandung Nitrogen}

Prekursor senyawa mengandung nitrogen adalah asam-asam amino hasil pemecahan dari protein. Sec-butil nitrit, 2,4-dimetilamfetamin dan piperazin ditemukan dalam penelitian ini. Belum ada laporan mengenai kedua senyawa ini pada produk tempe. Senyawa mengandung nitrogen yang dilaporkan Jeleń et al., (2013) adalah 2asetil-1-pirrolin dengan konsentrasi yang rendah yaitu $14 \mu \mathrm{g} / \mathrm{kg}$ pada tempe segar umur 1 hari.

Tabel 1. Senyawa-senyawa penyusun flavor tempe

\begin{tabular}{|c|c|c|c|c|c|c|c|c|c|c|c|}
\hline \multirow{2}{*}{ No. } & \multirow{2}{*}{ Senyawa } & \multirow{2}{*}{$\begin{array}{c}\text { Dasar } \\
\text { penentuan }\end{array}$} & \multirow{2}{*}{ RI Hasil } & \multirow{2}{*}{$\begin{array}{c}\text { RI } \\
\text { Literatur }\end{array}$} & \multicolumn{6}{|c|}{ Area (\%) } & \multirow{2}{*}{$\begin{array}{l}\text { Deskripsi } \\
\text { aroma }\end{array}$} \\
\hline & & & & & TD1H & $\mathrm{TD} 2 \mathrm{H}$ & TD3H & TP1H & $\mathrm{TP} 2 \mathrm{H}$ & TP3H & \\
\hline 1. & Metil 3-metilbutanoat & MS & $1027,1030,1034$ & $1035^{\mathrm{d}}$ & 2,51 & 0,57 & $\mathrm{Nd}$ & 6,34 & $\mathrm{Nd}$ & $\mathrm{Nd}$ & Green, bean \\
\hline 2. & a-pinen & MS, RIL & 1035 & $1035^{\mathrm{a}, \mathrm{d}}$ & 4,01 & $\mathrm{Nd}$ & $\mathrm{Nd}$ & $\mathrm{Nd}$ & $\mathrm{Nd}$ & $\mathrm{Nd}$ & Salty, bean \\
\hline 3. & Etil 3-metilbutanoat & MS & 1071,1072 & $1042^{c}$ & 3,72 & 0,86 & $\mathrm{Nd}$ & 2,34 & $\mathrm{Nd}$ & $\mathrm{Nd}$ & Acid, sour \\
\hline 4. & 2-metilpropanol & MS, RIL & $1103,1104,1105$ & $1103^{a}$ & $\mathrm{Nd}$ & 0,97 & 5,95 & $\mathrm{Nd}$ & 0,98 & 1,43 & Sweet, cereal \\
\hline 5. & 3-metilbutanol & MS & $1216,1217,1218$ & $1208^{\mathrm{a},} 1210^{\mathrm{c}}$ & 14,36 & 31,29 & 57,64 & 7,06 & 21,91 & 46,90 & Cereal, green \\
\hline 6. & 1,8-sineol & RIL & 1225 & $1224^{b}$ & 1,46 & $\mathrm{Nd}$ & $\mathrm{Nd}$ & 0,89 & $\mathrm{Nd}$ & $\mathrm{Nd}$ & Sour \\
\hline 7. & 2-pentilfuran & MS & $\begin{array}{l}1232,1233,1235 \\
1236,1237,1238 \\
1245\end{array}$ & $1226^{\mathrm{e}}$ & 2,30 & 3,56 & 1,71 & 1,45 & 0,54 & 1,20 & Cereal \\
\hline 8. & Piperazin & MS & 1260 & & $\mathrm{Nd}$ & $\mathrm{Nd}$ & $\mathrm{Nd}$ & $\mathrm{Nd}$ & 0,51 & $\mathrm{Nd}$ & Tidak terdeteksi \\
\hline 9. & Octan-3-on & MS & $\begin{array}{l}1263,1264,1265 \\
1266,1270,1271\end{array}$ & $1251^{f}$ & 13,28 & 6,97 & 2,95 & 16,18 & 6,47 & 7,13 & \\
\hline 10. & Sec-butil nitrit & MS & 1307 & & $\mathrm{Nd}$ & $\mathrm{Nd}$ & $\mathrm{Nd}$ & 1,22 & $\mathrm{Nd}$ & 0,63 & Cereal \\
\hline 12. & 1-heksanol & MS, RIL & $1360,1361,1362$ & $1362^{a, c}$ & 1,25 & 1,29 & 0,81 & $\mathrm{Nd}$ & 0,73 & 0,74 & Sour, creamy \\
\hline 13. & $\begin{array}{l}\text { 9-metiltetrasiklo } \\
{[7.3 .1 .0(2.7) .1} \\
\text { (7.11)]tetradecan }\end{array}$ & MS & $\begin{array}{l}1385,1386,1388 \\
1389,1393\end{array}$ & & 0,63 & 0,72 & $\mathrm{Nd}$ & 0,89 & 1,30 & 0,54 & Earthy \\
\hline 14. & Unknown & - & 1448,1449 & & $\mathrm{Nd}$ & $\mathrm{Nd}$ & $\mathrm{Nd}$ & 0,33 & 0,13 & $\mathrm{Nd}$ & Tidak terdeteksi \\
\hline 15. & 1-octen-3-ol & MS & $1454,1455,1456$ & $1448^{\mathrm{e}}, 1465^{\mathrm{b}}$ & 0,75 & 0,47 & $\mathrm{Nd}$ & 1,33 & 1,20 & 0,68 & Salty, bean \\
\hline 16. & a-kubeben & RIL & $1460,1462,1463$ & $1463^{h}$ & 1,96 & 2,59 & 1,71 & 1,06 & 2,09 & 1,08 & Salty, bean \\
\hline 17. & a-gurjunen & MS & $\begin{array}{l}1467,1468,1469 \\
1470,1471,1473 \\
1474\end{array}$ & $1529^{9}$ & 5,30 & 4,67 & 3,08 & 4,89 & 5,10 & 3,54 & Salty, bean \\
\hline 18. & Sitronellal & RIL & $\begin{array}{l}1492,1493,1494 \\
1495\end{array}$ & $1492^{\mathrm{a}}$ & 0,63 & 0,97 & $\mathrm{Nd}$ & 0,83 & 1,08 & 0,74 & Bean, creamy \\
\hline 19. & a-longipinen & MS & $\begin{array}{l}1518,1519,1520 \\
1521\end{array}$ & $1469^{g}$ & 1,54 & 1,62 & 0,60 & 1,78 & 2,31 & 1,45 & Sour, yeast \\
\hline 20. & Unknown & - & 1530 & & $\mathrm{Nd}$ & $\mathrm{Nd}$ & $\mathrm{Nd}$ & $\mathrm{Nd}$ & 0,57 & 0,56 & Sour \\
\hline 21. & $\begin{array}{l}\text { 2,3-dihidro- 7-metoxi- } \\
4 \text {-metil-1H- 1,5- } \\
\text { benzodiazepin- 2-on }\end{array}$ & MS & $\begin{array}{l}1547,1549,1550 \\
1551\end{array}$ & & 10,02 & 9,23 & 5,91 & 11,29 & 10,75 & 7,27 & Creamy, sour \\
\hline 23. & Unknown & - & 1609 & & $\mathrm{Nd}$ & $\mathrm{Nd}$ & $\mathrm{Nd}$ & $\mathrm{Nd}$ & 0,38 & $\mathrm{Nd}$ & Tidak terdeteksi \\
\hline 24. & Karyopilen & MS & $\begin{array}{l}1626,1628,1629 \\
1630\end{array}$ & $1618^{\mathrm{b},} 1641^{\mathrm{d}}$ & 32,90 & 28,59 & 19,64 & 38,38 & 36,02 & 23,72 & \\
\hline 25. & 2,4-dimetilamfetamin & MS & $1644,1645,1646$ & & 1,38 & 0,86 & $\mathrm{Nd}$ & 1,50 & 0,98 & 0,66 & Green \\
\hline 26. & Fenilasetaldehid & RIL & $\begin{array}{l}1649,1650,1651 \\
1652,1653,1663\end{array}$ & $1650^{\mathrm{a}}$ & 0,87 & 0,61 & $\mathrm{Nd}$ & 0,78 & 1,78 & 0,57 & Green, sour \\
\hline 27 & a-terpineol & RIL & 1700,1702 & $1700^{\mathrm{a}}$ & 0,42 & 0,47 & $\mathrm{Nd}$ & 0,56 & $\mathrm{Nd}$ & $\mathrm{Nd}$ & Sweet, green \\
\hline 28. & (Z)-a-bisabolen & MS & 1703 & $1740^{9}$ & $\mathrm{Nd}$ & $\mathrm{Nd}$ & $\mathrm{Nd}$ & $\mathrm{Nd}$ & 0,57 & 0,46 & $\begin{array}{l}\text { Green, } \\
\text { unpleasant }\end{array}$ \\
\hline 29. & Unknown & - & 1746 & & $\mathrm{Nd}$ & $\mathrm{Nd}$ & $\mathrm{Nd}$ & 0,95 & 0,25 & & Tidak terdeteksi \\
\hline 30. & (E)-tridec-2-enal & MS & 1772,1773 & & $\mathrm{Nd}$ & 0,36 & $\mathrm{Nd}$ & $\mathrm{Nd}$ & 0,89 & 0,57 & Bean, sweet \\
\hline 31. & Azulen & MS & 1778 & & $\mathrm{Nd}$ & 0,29 & $\mathrm{Nd}$ & $\mathrm{Nd}$ & 0,63 & $\mathrm{Nd}$ & Sour, sweet \\
\hline 32. & Etil fenilasetat & RIL & 1785,1786 & $1785^{a}$ & $\mathrm{Nd}$ & 0,40 & $\mathrm{Nd}$ & $\mathrm{Nd}$ & 0,76 & 0,31 & Earthy, sour \\
\hline 33. & Unknown & & 1899 & & $\mathrm{Nd}$ & 0,40 & $\mathrm{Nd}$ & $\mathrm{Nd}$ & $\mathrm{Nd}$ & $\mathrm{Nd}$ & Tidak terdeteksi \\
\hline 34. & 2-feniletanol & MS & 1937 & $1904^{9}$ & $\mathrm{Nd}$ & 1,19 & $\mathrm{Nd}$ & $\mathrm{Nd}$ & 0,67 & $\mathrm{Nd}$ & $\begin{array}{l}\text { Bean, cooked } \\
\text { bean }\end{array}$ \\
\hline 35. & $\begin{array}{l}\text { 2-methoxi-4- } \\
\text { methylphenol }\end{array}$ & MS & 1980,1981 & $1954^{9}$ & $\mathrm{Nd}$ & 1,08 & $\mathrm{Nd}$ & $\mathrm{Nd}$ & 0,76 & 0,57 & Sour, creamy \\
\hline $\begin{array}{l}\text { a Good } \\
\text { b Högr } \\
{ }^{c} \text { Fan \& } \\
\text { d Rous } \\
\text { e Butte } \\
\text { f Bianc } \\
\text { g Babu } \\
\text { h Choi, }\end{array}$ & $\begin{array}{l}\text { er, } 2008 \\
\text { dóttir \& Rouseff, } 2003 \\
\text { Qian, } 2005 \\
\text { ff, Onagbola, Smoot, \& } \\
\text { y, Orts, Takeoka, \& Nar } \\
\text { i, Careri, Mangia, \& Mu } \\
\text { hok, Linstrom, \& Zenke } \\
2003\end{array}$ & $\begin{array}{l}\text { telinski, } 2008 \\
, 1999 \\
\text { ci, } 2007 \\
\text { ich, } 2011\end{array}$ & & & & & & & & & \\
\hline
\end{tabular}


Berdasarkan hasil ini diketahui bahwa komponen utama flavor yang dihasilkan pada tempe yang dibungkus daun pisang dan plastik memiliki kesamaan. Perbedaannya terjadi pada konsentrasi senyawa yang dihasilkan, namun tidak jauh berbeda. Konsentrasi yang dimaksud bersifat kualitatif berdasarkan pada luas area pada masing-masing kromatogram. Penelitian lebih lanjut mengenai perbedaan konsentrasi ini diperlukan untuk mengetahui penyebabnya.

Yaakob et al., (2011) menyebutkan bahwa suhu fermentasi, waktu fermentasi dan starter yang digunakan merupakan hal yang penting selama proses fermentasi. Suhu fermentasi akan mempengaruhi pertumbuhan mikroorganisme dan aktivitas enzim yang dihasilkan selama proses fermentasi. Pada penelitian ini tidak ada perbedaan suhu fermentasi, karena fermentasi terjadi pada ruang khusus fermentasi. Namun demikian, perbedaan suhu internal tempe selama fermentasi dapat saja terjadi karena perbedaan kemasan yang digunakan. Daun pisang dapat menyerap panas dan mentransfer panas, sedangkan plastik tidak demikian. Sehingga diperlukan penelitian lebih mendalam mengenai hal ini.

Dilihat dari komponen utama penyusun flavor, penggunaan bahan pembungkus yang berbeda juga tidak memberikan perbedaan terhadap pembentukan flavor. Komponen utama flavor tempe yang dibungkus daun pisang maupun plastik disusun oleh 3-metilbutanol, octan-3-on, a-gurjunen, 2,3-dihidro-7-metoxi-4-metil-1H1,5-benzodiazepin-2-on dan karyopilen.

\section{KESIMPULAN}

Hasil penelitian diperoleh bahwa komponen flavor tempe disusun oleh golongan ester, terpenoid, alkohol, aldehid, keton, furan dan senyawa mengandung nitrogen. Komponen flavor utama yang dihasilkan pada produk tempe adalah 3-metilbutanol, 3-octanon, a-gurjunen, 2,3dihidro-7-metoxi-4-metil-1H-1,5-benzodiazepin-2-on dan karyopilen. Ada perbedaan senyawa-senyawa yang terbentuk pada tempe yang dibungkus daun pisang dan plastik yaitu a-pinen hanya ditemukan pada tempe yang dibungkus daun pisang saja sedangkan piperazin, secbutil nitrit dan (Z)-a-bisabolen hanya ditemukan pada tempe yang dibungkus plastik saja.

\section{DAFTAR PUSTAKA}

Apriyantono, A., Nurkori, Nurjanah, S., \& Satiawihardja, B. (2001). Food Flavors and Chemistry. In A. M. Spanier, F. Shahidi, T. H. Parliment, C. Mussinan, C.-T. Ho, \& E. T. Contis (Eds.), Food Flavors and Chemistry Advances of the New Millennium (pp. 171-182). Cambridge: The Royal Society of Chemistry.

Babushok, V. I., Linstrom, P. J., \& Zenkevich, I. G. (2011). Retention Indices for Frequently Reported Compounds of Plant Essential Oils. Journal of Physical and Chemical Reference Data, 40(4). https://doi.org/10.1063/1.3653552

Bianchi, F., Careri, M., Mangia, A., \& Musci, M. (2007). Retention indices in the analysis of food aroma volatile compounds in temperature-programmed gas chromatography: Database creation and evaluation of precision and robustness. Journal of Separation Science, 30(4), 563-572. https://doi.org/10.1002/jssc.200600393

Buttery, R. G., Orts, W. J., Takeoka, G. R., \& Nam, Y. (1999). Volatile flavor components of rice cakes. Journal of Agricultural and Food Chemistry, 4オ10), 4353-4356. https://doi.org/10.1021/jf990140w

Carballo, J. (2012). The Role of Fermentation Reaction in the Generation of Flavor and Aroma of foods. In B. M. Mehta, A. Kamal-Eldin, \& R. Z. Iwanski (Eds.), Book Fermentation Effects on Food Properties (pp. 51-88). New York: CRC Press.

Choi, H.-S. (2003). Character impact odorants of Citrus hallabong (Citrus unshiu Marcov x Citrus sinensis Osbeck) $x$ C. reticulata Blanco) cold pressed peel oil. Journal of Agricultural and Food Chemistry, 51(9), 2687-2692. https://doi.org/10.1021/jf021069o

Elmore, J. S., Campo, M. M., Enser, M., \& Mottram, D. S. (2002). Effect of lipid composition on meat-like model systems containing cysteine, ribose, and polyunsaturated fatty acids. Journal of Agricultural and Food Chemistry, 50(5), 1126-1132. https://doi.org/10.1021/jf0108718

Fan, W., \& Qian, M. C. (2005). Headspace solid phase microextraction and gas chromatography-olfactometry dilution analysis of young and aged Chinese "Yanghe Daqu" liquors. Journal of Agricultural and Food Chemistry, 53(20), 7931-7938. https://doi.org/10.1021/jf051011k

Goodner, K. L. (2008). Practical retention index models of OV101, DB-1, DB-5, and DB-Wax for flavor and fragrance compounds. LWT - Food Science and Technology, 41(6), 951-958. https://doi.org/10.1016/j.lwt.2007.07.007

Högnadóttir, Á., \& Rouseff, R. L. (2003). Identification of aroma active compounds in orange essence oil using gas chromatography-olfactometry and gas chromatographymass spectrometry. Journal of Chromatography A, 998(12), 201-211. https://doi.org/10.1016/S00219673(03)00524-7

Jeleń, H., Majcher, M., Ginja, A., \& Kuligowski, M. (2013). Determination of compounds responsible for tempeh aroma. Food Chemistry, 141(1), 459-465. https://doi.org/10.1016/j.foodchem.2013.03.047

Kustyawati, M. E. (2009). Kajian peran yeast dalam pembuatan tempe. Agritech, 29(2), 64-70.

Liu, Y., Miao, Z., Guan, W., \& Sun, B. (2012). Analysis of organic volatile flavor compounds in fermented stinky tofu using SPME with different fiber coatings. Molecules, 174), 3708-3722. https://doi.org/10.3390/molecules17043708

Mei Feng, X., Ostenfeld Larsen, T., \& Schnürer, J. (2007). Production of volatile compounds by Rhizopus oligosporus during soybean and barley tempeh fermentation. International Journal of Food Microbiology, 113(2), 133141. https://doi.org/10.1016/j.ijfoodmicro.2006.06.025

Rouseff, R. L., Onagbola, E. O., Smoot, J. M., \& Stelinski, L. L. (2008). Sulfur volatiles in guava (Psidium guajava L.) leaves: Possible defense mechanism. Journal of Agricultural and Food Chemistry, 56(19), 8905-8910. https://doi.org/10.1021/jf801735v

Shurtleff, W., \& Aoyagi, A. (1979). The Book of Tempeh. New York: Harper and Row Publishers.

Supriyanto, Wada, K., Hayakawa, I., \& Fujio, Y. (1991). Principal Component Analysis of Aroma Profiles of Tempeh Produced by Using Various Starters. Hakkokogaku, 69, 331-336.

Van Ba, H., Ryu, K. S., \& Inho, H. (2012). Flavor characteristics of Hanwoo beef in comparison with other Korean foods. 
Asian-Australasian Journal of Animal Sciences, 25(3), 435446. https://doi.org/10.5713/ajas.2011.11286

Vranová, J., \& Ciesarová, Z. (2009). Furan in food - A review. Czech Journal of Food Sciences.

Yaakob, H., Malek, R. A., Misson, M., Jalil, M. F. A., Sarmidi, M. R., \& Aziz, R. (2011). Optimization of isoflavone production from fermented soybean using response surface methodology. Food Science and Biotechnology, 20(6), 1525-1531. https://doi.org/10.1007/s10068-011-0211-6

Yaylayan, V. A. (2006). Precursors, formation and determination of furan in food. Journal Fur Verbraucherschutz Und Lebensmittelsicherheit, 1(1), 5-9. https://doi.org/10.1007/s00003-006-0003-8 